tive thoory. Quasars were recognized too lato to be discussed in this book.

More advanced chapters include a thoughtful one by R. Kipponhahn, containing more than is impliod in its title, "Stars with Holium-Rich Cores"; it not only discusses problems associatod with models of giant (class III) stars, but also gives some considoration to difficult quostions rolating to internal magnetic fields and intornal circulation of matter (Figs. 15 and 17 in this article seem to have boen interchanged). Experionced workors are likely also to find valuable reading in chapters by $P$. Ledoux, "Stellar Stability and Stellar Fvolution"; by N. Bakor, "Theoretical Models for the Pulsations of Cepheids"; and F. Schatzman, "The Early Stages of Stollar Evolution". M. M. Shapiro contributes "Notes on Cosmic Radiation", a brief summary of present knowlodgo with regard to mass and onergy distributions among cosmic-ray particles, with some discussion of their origin and of the question of their confinement in the Galaxy.

There are varied contributions of a more observational naturo by L. Gratton, E. M. Burbidge, L. Rosino, and M. Hack respectively, ranging ovor such subjects as stellar associations, $T$ Tauri and related variablo stars, observed abundance anomalios, the structure of galaxies and the evolution of close binaries. Without questioning the value of these contributions, what I missed was a thorough survoy omphasizing tho basic observational neods in this subject, for better and more stollar photometry, better distanco determinations, better mass detorminations, better chomical abundances (involving much laboratory measurement as well as obsorvatory investigations), more propor motions, more radial velocitios, otc. In tho case of soveral of these, for example, distances and masses, there is a crying need for good technical innovation. Thoory has outrun the observational chocks, and without them is in danger of indulging in excessive speculation and of getting too far away from tho roal, physical, world. Unfortunately, the acquisition of roliable obsorvational data involves a groat deal of hard, unglamorous work that cannot be done by unskillod labour, that is useless if not dono critically and conscientiously, and that at the present day gets no great thanks or recognition even when well done. Astronomy, indeed all physical seience, owes more to the Puritans than it has ever cared to acknowledge, and the decay of Puritan idoals in the Western world makes it more and more difficult to find poople to do unpopular work, howover essential. I think it is spocially important to bring such points to the notice of young research workers.

The book is rather heterogeneous, but contains some good reading. It is well printed but could have been better odited.

R. O. RGDMAN

\section{LOOKING AT DISLOCATIONS}

\section{The Direct Observation of Dislocations}

By S. Amelinckx. (Solid Stato Physies: Advaneess in Rosonreh and Applications, Supplement 6.) Pp. $\mathrm{x}+487$. (New York: Acadomic Pross, Ine.; London: Academic Pross, Inc. (London), Ltd., 1964.) $121 s .6 d$.

T is remarkable how the study of dislocations in crystals I has transformed itsolf, ovor tho past fiftoen years, from a thoorotical science into an experimental one. Whon the basic theory was laid down, during the period 1934 50 , dislocations seemod to many peoplo to bo mere playthings of tho theoretician, never seen except on blackboards and backs of envelopos. Admittedly, there were some early signs that the theory might bo corroct--for oxample, from the Tragg bubble inodel and from the observation of the formution and movernent of low-angle tilt boundarics in bent crystals-- but tho ossontial oxporimental challenge of actually seeing dislocations in crystals still remainod.
Then, quilo suddenly, everything chunged and soveral direct methods of observation appeared. In accordance with F. C. Frank's thoory, growth spirals were seen to emanate from points of emorgence of dislocations on crystal faces. In transparent crystals the 'decoration' tochnique was dovoloped for showing up dislocations by lines of precipitated particles, liko tracks in a cloud chamber. X-ray methods were also doveloped. Most important of all, the thin-film transmission electronmicroscope techniques were discovered, which allowed dislocations to be seen so easily inside crystals that films could be taken of thoir movemonts. More recently, the field-ion microscope has enabled the atomic structures of dislocations to be seen.

These developments have set off a world-wide activity in the experimental study of dislocations. Many Ph.D.s havo been won and many beautiful photographs published in this enterprise. A whole now subject has grown upthe erystallography of imperfect crystals-with its own body of theory for interpreting the observations and for identifying and classifying tho dislocations thus seen, with an exactitude equal to that of elassical crystallography.

Prof. Amelinckx has played a loading part in this development, particularly in the decorntion of dislocations in ionic crystals, and it is no surprise that he has written this excellent and authoritativo book. The principal oxporimontal methods are described in groat detail, illustrated with many suporb pictures of dislocations, and the theory necessary for the interpretation of the observations is dovoloped fully. 'This book can be unreservodly recommended to solid-stato physicists and metallurgists interested in the experimental study of dislocations. They will bo oncouraged to work in the field by the dolightful combination of experimont and theory it offers and which is so well brought out in this book. They need have no fear that all the interesting work has now been done: the field is an immensely rich one, as yet almost untouched in some areas, and this book will bo an invaluable guide for all expeditions into them. A. H. Cottrel

\section{PHYSICAL GEOLOGY UP-TO-DATE}

\section{Principles of Physical Geology}

By Prof. Arthur Holmes. New and fully rovisod edition. Pp. $x v+1288$. (London and Edinburgh: Thomas Nelson and Sons, Ltd., 1965.) 84s. not.

CINCE Principles of Physical Geology first appeared $\checkmark$ twenty years ago profound re-orientations have occurred in many branches of geology and especially in those whero modern advances in physies and allied disciplines have been used to illuminate goological problems. $\Lambda$ fow oxumples will emphasize the wide rango and great depth of these changes. Radiometric dating has bronght order into cryptozoic chronology so that the fundamental evonts of the first three thousand million years of tho history of the Earth can be arranged in a reasonable sequence. Large-scale exploration by novel methods, geophysical and onginesring, has completely changed idoas on the form and structure of tho ocoan floors which, after all, constitute 70 per cent of the lithosphoro. Detorminations in the rocks of many ages of the attitude of the Farth's magnetic field at tho timos they were formed, combined with the investigations of ancient climates and even of ancient wind-diroctions, have transformed the formor heresy of continental drift into a fairly respectable orthodoxy. Now ideas on the behavionr of rocks undor various stross conditions havo ohunged tho interpretation of many crustal structures and hnvo profoundly modified speculations coneerning happenings in tho dosper sholls of the Farth. Prof. IIolmos has played a prominent part in many of theso advances, and they, with countless others, are set forth with his customary clarity and sprightliness 